\title{
THE RURAL DEVELOPMENT PLANNING IN INDIAN ECONOMY - A NEW CENTURY
}

\author{
V. Prabakaran \\ Ph.D. Research Scholars, Alagappa Institute of Management, Alagappa University, \\ Karaikudi, Tamil Nadu, India \\ Dr. C.K. Muthukumaran \\ Professor, Alagappa Institute of Management, Alagappa University, \\ Karaikudi, Tamil Nadu, India \\ M. Manida \\ Ph.D. Research Scholars, \\ Department of Commerce' Alagappa University, \\ Karaikudi, Tamil Nadu, India
}

\begin{abstract}
This article talks about the economic status of provincial India. It centers on the present status of provincial regions and the emerging powers that will change life in rustic territories through the mid twenty-first century. During the twentieth century, innovation disintegrated the business base of most country networks, discouraged earnings, and made out-relocation the main plan of action for millions. The fortunes of rustic networks are peripatetic. Some are proceeding to meet financial decrease. Others are attempting to adapt to quick development in the populace, land use clashes, and developing interest for open administrations. The twenty-first century could rather support provincial networks. Monetary and segment patterns are diminishing the expense of separation and expanding the estimation of the opportunity. Innovation is lessening the requirement for proximate workers. Interest in the provincial network way of life is developing. With viable provincial policy, rural networks could contribute considerably more to the national economy.
\end{abstract}

Key words: MGNREG, NITI, Model Contract Farming Act, Integrated Wastelands Development Programme, JGSY.

Cite this Article: V. Prabakaran, Dr. C.K. Muthukumaran and M. Manida, The Rural Development Planning in Indian Economy- A New Century, International Journal of Management, 11(12), 2020, pp 2856-2863.

http://iaeme.com/Home/issue/IJM?Volume=11\&Issue=12 


\section{INTRODUCTION}

Provincial improvement is the will be the spine for any nation's financial improvement and its causes the economy to develop and support. Rural development is the revolve of the economy, including the work morals affecting the capability of business in a large manner. It is a widespread view that financial progress happens due to fast industrialization. Be that as it may, the up to date advancement itself can't happen without farming. In particular, agribusiness adds to monetary advancement by item commitment and market commitment. Rural division is the long haul procedure for the monetary advancement. Rural improvement is a theme that is entirely straightforward yet difficult to execute. It centres upon the development and advancement of the segments of country economies that experience grave destitution issues and successfully targets building up their profitability. It likewise accentuates the need to address different problems that are begging to be addressed of town economies that prevent development and improve these territories. A few zones that need pressing consideration for Rural Development in India are:

- General well being and sanitation

- Proficiency

- The Female is strengthening

- Implementation of lawfulness

- Land changes

- Foundation advancement like water system, power, and so forth.

- Accessibility of credit

- Annihilation of destitution

\section{REVIEW OF LITERATURE}

Ashish Mathur (2011), in his article entitled "The Dimensions of Indian Rural Development: Issues and Challenges" observed that researcher explained economic environment and the noneconomic environment. Every nation should depend on the environment. The economies are affected by the national and the universal condition. The non-monetary condition comprises of the socio-social condition, characteristic segment physical and the world of politics. The monetary components of the provincial condition straightforwardly put an effect on the Indian business advertise. The business needs to comprehend the requirements of the provincial condition and change as indicated by the rustic markets so improve the incentive to the general public.

Dr. S. Vijay Kumar (2018), in his article entitled "Rural Development in India - A Way Forward" Observed that country improvement projects should consolidate foundation advancement, education, health administrations, interest in horticulture and the advancement of rustic non-ranch exercises in which ladies and provincial populace can draw in themselves. Provincial improvement and rustic entrepreneurship are the method for changing over the forming nation into the created country. Advancement of country business enterprise is critical with regards to creating beneficial work and diminishing the extending variance between the rustic and urban. Checking provincial improvement programs by providing the right data at the opportune time, giving auspicious and sufficient credit and nonstop inspiration of brokers, Panchayat association pioneers and deliberate assistance associations will prompt the advancement of rustic business and thusly country improvement.

Thomas G. Johnson (2001), in his paper entitled "Rural Economy in a New Century the Rural Economy in A New Century" Highted that Disconnected rustic networks will commonly 
exist at significant good ways from urban focuses. These people groups will be those that have endured a time of critical provincial solidification- that is, the decrease of a few and adjustments of others. The greater part of these networks will be in the upper fields and western areas, despite the fact that pockets of disengagement will exist in all locales.

\section{NEED FOR RURAL DEVELOPMENT IN INDIA}

The country's economy is a case of an agrarian economy. Albeit cultivating and farming are one of the most significant essential exercises, the issue lies in the way that they share in the GDP of the horticulture segment is on a consistent decrease. Simultaneously, around $66 \%$ of India's populace rely upon agribusiness. Accordingly, the profitability isn't sufficient, with conditions just deteriorating.

\section{SCOPE FOR IMPROVEMENT}

The essential zone to improve ought to give work in rustic territories and improving the profitability of the agrarian part. Frequently towns in our nations are not in a state of harmony with the urban territories due to awful network. In the long run, this prompts isolation and a social partition among urban and rustic regions. Fundamentally, the foundation of provincial territories ought to definitely improve. Much after such a large number of long stretches of Independence, marks of shame like the standing framework despite everything have a grasp on provincial individuals. Quality training can help in accomplishing the objective of the destruction of such social disasters. The waning education rates in country India, particularly for females, are a significant matter of concern. There is a requirement for land and specialized changes. Current advancements like natural cultivating ought to be consolidated to improve yields and benefits. In conclusion, individuals ought to be offered access to simple credit and advances by improving the financial framework in rustic regions. It tends to be effortlessly finished up, that for the advancement of an economy in both provincial and urban territories should be engaged upon. Provincial regions need uncommon changes in regions like foundation, credit accessibility, education, destitution destruction, and so forth. The plans that are now set up to the point of provincial improvement need another standpoint and appropriate refreshing. As needs be, the administration needs to represent the upliftment of country India.

\section{OBJECTIVES}

- To study on the India needs a new deal in rustic India.

- To determine the rural economic development Planning in India.

\section{INDIA NEEDS A NEW DEAL FOR RUSTIC INDIA}

As our economy creates in some cases quick and now and again hesitantly the change is clear to all, regardless of whether they are associated with the progression of India. When these are not known, it blends a feeling of disdain among the discouraged. When these are not known, it mixes a feeling of hatred among the discouraged. We ought to in this manner guarantee that the advantages of budgetary development contact each and every resident of India right now throughout the entire existence of India. In the event that not, on the off chance that the standards of dissimilarity and desires kick the pail, at that point our endeavors to make a prosperous India won't demonstrate productive. Regardless of the discoveries of the examination of the potential and utilization of M-Services in changing the district expansion administrations and superficially at more ranchers through the modernism empowered way of activities, little has been knowledgeably by the situation increase direction to date; this is 
because of low financing of the regional expansion administrations and the decrease in the quantity of augmentation operators through privatization of the growth management.

\subsection{Financial Polices}

Downfall in common India is no matter how you look at it with the normal yearly getting of a little and unimportant rancher family at ₹79,779 in 2015-16, as indicated by the Committee on Doubling of Farmers' Income. The uniqueness in per capita ordinary and urban remuneration have remained solidly high, with a common urban specialist making sure about more than various events a conventional rural master, as per NITI Aayog conversation paper Changing Structure of Rural Economy of India, Implications for Employment and Growth. The extending urban-country separate is likewise clear in the operations being used, singular satisfaction, and accessibility of physical and social structure. To guarantee total cash related improvement, the association needs to frantically concentrate on changing the agrarian economy to pull the most phenomenal number of individuals out of subsistence creating and give them a widely progressively profitable movement. With $66 \%$ of India's at any rate billion individuals living in towns, initiating the cash related motor of typical India will have a multiplier influence on experience, use, government use and sections. The capacity of common India can be checked by the way that plant new associations have brought almost $\$ 130$ million up in around 70 strategies in the previous five years to 2018 , as showed by a news report. It should concentrate on agri-headways that can reinforce commonplace adequacy, make respect included ranch things and tap "homestead to-fork openings" to guarantee better insistence for ranchers. It will additionally need to make innumerable tinier degree delegates and a gigantic number of monetary, social events in rustic India, other than putting resources into country streets, basic power, water system structures and national contamination chain cross segments. The improvement of our homeland with a point of view to pick up the individual fulfilment of the general people is said to be regional improvement.

\subsection{Loan Waivers need a Rethink}

India truly needs to reconsider its present answers for easing provincial torment, a gigantic piece of which are as either gives or credit waivers. These have by and large neglect to reduce urgency and confirmation pay security for an overarching bit of Indians utilized in creating. There are various reports of rancher suicides from the nation over as shown by capita pay of ranchers have developed scarcely. The Accidental Death and Suicide in India report for 2015 showed that dependably at any rate 34 ranchers completed it all in India (12,602 suicides in the year), by and large by the goodness of area 11 or indebtedness. We should change the way wherein we are taking a gander at utilizing government help supporting. Government help supporting doesn't fix or address the essential driver of sadness; it just treats the responses. The rule driver of neediness is about nonattendance of aptitudes and budgetary chance. So government help financing ought to be anticipated evacuating these limits in the strategy for supportable ordinary movement. Let us take the Mahatma Gandhi National Rural Employment Guarantee (MGNREG) program, which gives in any event 100 days of ensured wage business each budgetary year to each family whose grown-up individuals volunteer to accomplish blundering manual work. Does the program guarantee feasible movement for the staying 265 days of the year? Are the wages enough to lift them out of urgency? Is the program helping upskill these country laborers? The response to these solicitations is no. Instead of work planned occupation creation, the MGNREGA should push information drove work creation, or, by the day's end the program ought to request that ranchers find a few solutions concerning headway, and it ought to apply improvement to become their getting limits. Right now age, utilizing the work to burrow wells or lay paths is truly not a sharp strategy for utilizing human capital. In any case, if human capital is secured with information and limits, we will squander an immense 
asset. This is the clarification the MGNREGA needs a reboot. Rather than taking a gander at the typical workforce as workers, our policymakers should push toward them as a key human asset.

\subsection{Need for Entrepreneurship}

To re-invigorate the country's economy, the Modi government has been attempting to acquire some approach changes like e-markets, rancher maker associations (FPOs) and the Model Contract Farming Act, 2018. As Indian ranchers have the littlest landholding on earth, they need singular dealing limit in the open market for their little produce. In such a situation, the making of FPOs can give them a serious edge since they can pool in their produce, put resources into cold storerooms and better haggle with huge buyers. At a similar time, I trust FPOs need to go past simply being "cultivating cooperatives" and change themselves into flourishing enterprise bunches. The FPO model ought to be extended with countless motivating forces. The administration needs to step in to make a couple of model FPOs in the nation. An authority from the farming service can assume the job of an empowering agent and facilitator in these model FPOs and guarantee they gain admittance to impose and different motivating forces. A judicious arrangement for FPOs will urge farming business people to feel free to imitate the achievement of the celebrated milk agreeable brand Amul. FPOs can be an extraordinary model for esteem included agribusiness. For instance, an FPO of ranchers who produce Ragi or finger millet, a mainstream staple in the eating regimen of an enormous number of individuals in Karnataka, can begin making esteem included items from their harvest. Actually, with the Karnataka government advancing ragi as super nourishment, equivalent with quinoa, there is an incredible open door for a FPO to see making esteem included items like ragi wellbeing drinks, multigrain noodles, ragi bread rolls, ragi vermicelli and so on. A whole smaller scale enterprise bunch can come up to supply to a prepared urban market, consequently guaranteeing a long haul, economical wellspring of pay for the farmers. In actuality, these FPOs can tie up with business colleges to assemble the skill for building up a vigorous pioneering environment that prompts the production of an energetic provincial economy. In the event that we can make towns that can legitimately offer products to worldwide markets, then we will see the far reaching influence of a small scale innovative economy moving through rustic India.

\subsection{Making Rural Folk Tech Savvy}

While savvy government strategies, monetary incorporation activities and interests in foundation can help, more prominent utilization of innovation can fire the enterprising soul and prod advancement in provincial India. Innovation can likewise assist ranchers with getting to great sources of info, crop wellbeing and yield information and essential climate related data. Additionally, utilizing innovation and information science can help manufacture progressively proficient stockpile chains that interface retail markets with nourishment processors and FPOs. Online life stages can help associate ranchers to the bigger economy. In the event that WhatsApp messages can arrive at each and every voter in India, the stage can be utilized to teach ranchers, change them into miniaturized scale business visionaries and associate these rustic business people to national and universal markets. More noteworthy access to innovation has just prompted the development of social endeavor new companies that are concocting applications to help improve the lives of rustic people. A more noteworthy push to these new businesses can procure rich profits. Sustainable Rural development contrasts as indicated by space, time, values and accessible assets. The development practice of the nation association from the maintainability point of view initially suggests the attention to the improvement necessitate, of the accurate evaluation of qualities and shortcomings of the nation arrangement, of existing or potential chances and dangers, which will decide the require activities in the short and long haul. 


\subsection{Utilizing Biotech in Farming}

In spite of the fact that farming adds to about $17 \%$ of India's total national output (GDP), its noteworthiness to the individuals of India can't be over stressed. Notwithstanding taking care of the nation, horticulture has almost $50 \%$ of our 1.3 billion or more populace relying upon it for their job. The awful news is horticultural development is easing back. Between monetary 2014 and 2019, agri-GDP developed at $2.9 \%$ every year contrasted and a $3.7 \%$ per yearly development between financial 2005 and 2014. At a similar time, environmental change compromises India's harvest creation. While the outrageous precipitation occasions have become successive and increasingly a factor, the seriousness and recurrence of dry spells has additionally expanded since 1970s. The use of biotechnology can streamline the utilization of accessible assets without setting extra requests ashore or water to support yields, which is the thing that India needs. These arrangements, which can be effectively scaled the nation over, can improve the nature of the produce with illness free and healthfully upgraded assortments of harvests. Biotechnology can likewise create monetary chance, venture and work in the horticulture division through the improvement of new assortments of harvests, new uses for crop deposits and waste, just as, supporting the advancement of new markets for ranch produce. It offers immense potential to drive enhancements in rural efficiency and productivity, in this manner, giving chances to guarantee monetary prosperity of the rancher alongside nourishment security for the country. The Indian government has set up a few places of plant sub-atomic science and yield biotechnology. Additionally, various horticultural colleges in the nation have begun their own biotechnology programs with budgetary help from nearby governments, and national and universal subsidizing offices. Agri-biotechnology is being applied across poultry and dairy cultivating, fisheries, gardening, agriculture, the nourishment handling industry, and hereditarily changed (GM) innovation. Indian ranchers who settled on Bt cotton, which is the main GM crop took into consideration business development in the nation, profited by more significant returns and decreased pesticide use. Over $90 \%$ of the nation's cotton developing regions are today under Bt Cotton, and India has risen as the biggest maker and second biggest exporter of cotton on the planet. Agreeing an ongoing article by notable farming market analyst, Ashok Gulati, India increased about $\$ 67$ billion in the remote trade from additional fares of cotton and cotton yarn, and reserve funds in imports, over FY03-FY17. Significantly, salaries of cotton ranchers multiplied because of reception of Bt Cotton.

\section{PROVINCIAL PLANNING IN INDIA DEPENDS ON DIFFERENT ISSUES. THE CENTRAL REGIONS OF PROGRESS INCLUDE}

- Rural framework habitant advancement

- Poverty decrease

- Provision of essential least assistance

- Service age

Construction open basic necessities in request to address these issues of the country India, the Indian administration had propelled different rustic plans. A short depiction of individual plans has been given beneath:

Sampoorna Gramin Rozgar Yojana (SGRY): An independent work program for the rustic individuals in which all vital money related assistance, framework, preparing, and soon be known.

Rural Housing (Indira Awaas Yojana): A previous sub-plan of Rural Landless Employment Guarantee Program, IAY encourages the development of houses for the provincial destitute and denied. The vision is to build up pucca houses for all by the appearance of the eleventh Plan. 
Training Schemes: Foundations like NIRD have taken up attempts in preparing, classes, workshops, and global projects.

E-NAM: E-NAM addresses these technical hitches by creation a joined commercial center through network exchanging crossroads, together, at location and nationwide estimation and advances steadiness, reshuffle of systems in excess of the arranged markets, evacuates information irregularity among buyer and merchants and advances ceaseless regard disparity, in context of certified premium and supply, moves bluntness in bargain procedure, and right of section to a the country over report for the agriculturist, with costs equivalent with view of his pass on an online segment and trustworthiness of better greatness make and at dynamically sensible costs to the client.

Other programs and schemes facilitating rural planning are Accelerated Rural Water Supply Programme, Jawahar Gram Samridhi Yojana (JGSY), Drought Prone Areas Programme (DPAP), and Integrated Wastelands Development Programme (IWDP). Provincial Planning in India has surely become a fundamental piece of the advancement of the nation's economy and the Ministry of Rural Development is assuming a critical job right now. External organizations are relied upon to make some helpful strides for the manufacture of accumulated network.

\section{CONCLUSION}

To terminate positive, to launch the country's economy, we should define arrangements that emphasis on helping individuals rise up out of a presence of unending disservice through impetuses not handouts. A crossing over of the urban-rustic partition is basic for long haul practical development of the economy. Rustic India is at a junction. During the twentieth century, innovation disintegrated the work base of most rustic networks, discouraged earnings, and made out-relocation the main plan of action for millions. In the twenty-first century, innovation may turn around that inclination and rather favor rustic networks and country inhabitants. The Country people group faces various obstacles before these powers will work to further their potential benefit as opposed to disadvantage. The fortunes of rustic networks are wandering. Some are proceeding to confront conventional monetary hardships and decay. Others are attempting to adapt to quick development in employments and populace, land-use clashes, and developing interest for open administrations. With a continuation of current arrangements, there is little motivation to expect this procedure of dissimilarity will ease. On the other hand, monetary and innovative patterns are diminishing the expense of separation and expanding the estimation of the opportunity. Innovation is lessening the requirement for work, particularly proximate work. Interest for the sort of way of life accessible in country networks is developing. There are motivations to be circumspectly idealistic. There are positively motivations to investigate the probable in favour of business expansion and to look used for new motors of regional growth. With new, successful outmoded strategy, nation networks can contribute significantly more to the essentials of the national economy.

\section{REFERENCES}

[1] Ashish Mathur, The Dimensions of Indian Rural Development: Issues and Challenges, International Journal of Contemporary Practices - Vol. 1, Issue. 2 (June, 2011) ISSN: 22315608 .

[2] Dr. S. Vijay Kumar (2018), Rural Development In India - A Way Forward, www.researchgate.net/publication/328289155_Rural_Development_In_India- Way_Forward.

[3] Thomas G. Johnson, Rural Economy in a New Centurythe Rural Economyin A New Century, International Regional Science Review (Vol. 24, No. 1, 2001). 
[4] Dr.G. Nedumaran, M. Manida, M.Arul Kumar, M. Alaguraja,. (2020). Effect of Mobile Applications on Farming in Virudhunagar District -A Study, Our Heritage, Vol-68-Issue-1January-2020, ISSN: 0474-9030.

[5] M. Manida, Dr.G. Nedumaran, V. Prabakaran, M. Arul Kumar, M.Alaguraja, Challenges and Possible of Organic Farming, Journal of Xidian University,Vol-14, Iss-3, 2020, ISSN: 10012400 .

[6] M. Manida, V. Prabakaran, M. Arul Kumar, Challenges of Organic Farming on Rural Development in Tamilnadu, Dogo Rangsang Research Journal, Vol-10 Issue-08 No. 02 August 2020, ISSN : 2347-7180

[7] Dr.G.Nedumaran, M.Manida, Trends and Impacts of E-Nam in India, ISBN:978-81-8094-3232, https://www.researchgate.net/profile.

[8] G. Nedumaran, M. Manida, Impact of FDI in Agriculture Sector in India: Opportunities and ChallengesInternational Journal of Recent Technology and Engineering (IJRTE), Volume-8, Issue-3S, October 2019, ISSN: 2277-3878.

[9] M. Manida, G.Nedumaran (2019), Impact of E-Communication on Agriculture Development through CSR in Agri-Farmer in Rajapalayam Taluk, The International journal of analytical and experimental modalanalysis. XI. 106-114. ISSN NO: 0886-9367.

[10] M.Manida, \& P.K.Pandiyaraj (2015), A Study on Consumer Behaviour towards Usage of Green Products, April 2015, DOI: 10.13140/RG.2.2.28781.13286.

[11] Manjula.N.Patil (2016), "Rural Development In The 21st Century"XVII Annual International Seminar Proceedings; January, 2016, ISBN no. 978-81-923211-8-9.

[12] D. Gangopadhyay, A.K. Mukhopadhyay \& Pushpa Singh (2008), Rural Development: A strategy for poverty alleviation in India,India, S\&T for Rural India and Inclusive Growth, India, Science and Technology: 2008.

[13] N. A. Mujumdar (2006), Centrality of Agriculture to India's Economic Development, Economic and Political Weekly, Vol. 41, No. 1 (Jan. 7-13, 2006), pp. 31-34 (4 pages).

[14] Dr BK Mukhopadhyay, Gearing Up to Face 21st Century Rural Development Challenges,Sentinel Digital Desk, 28 Aug 2018, www.sentinelassam.com/editorial/gearing-upto-face-21st-century-rural-development-challenges/?infinitescroll=1

[15] www.toppr.com/guides/economics/rural-development/rural-development-in-india 